Journal of Social Sciences (COES\&RJ-JSS)

ISSN (E): 2305-9249 ISSN (P): 2305-9494

Publisher: Centre of Excellence for Scientific \& Research Journalism, COES\&RJ LLC

Online Publication Date: $1^{\text {st }}$ April 2017

Online Issue: Volume 6, Number 2 Special, April 2017

http://centreofexcellence.net/J/JSS/JSS\%20Mainpage.htm

\title{
Pre-Service- Education and Practice-Teaching Performances among the Fourth Year Bachelor of Elementary Education Students of Mindanao State University- Maigo School of Arts and Trades Margarita C. Paghasian \\ Mindanao State University- Maigo School of Arts and Trades Maigo, Lanao del Norte, Philippines
}

\begin{abstract}
:
Teacher-education institutions are established to provide quality and holistic pre-service education to prospective teachers. This study was conducted to specifically look into the Pre-service-Teacher Education (PTE) in terms of personal preparation, professional preparation and classroom management and Practice-Teaching Performances (PTP) among the fourth year Bachelor in Elementary Education (BEEd) students of Mindanao State University-Maigo School of Arts and Trades (MSU-MSAT). This study measured the level and relationship of PTE of the students and their PTP. It employed descriptive method which involved all the 30 fourth year BEEd students. The data were derived through a questionnaire; and chi-square was used for the statistical computation. Results revealed that the fourth year BEEd students had an outstanding performance in personal professional preparations, classroom management and had good performance in practice teaching, but average in English and Filipino languages. Since the computed chi-square values were more than the critical values with one degree of freedom, the null hypotheses were rejected implying that PTE and PTP had significant relationship. In conclusion, PTE teachers have an appreciable performance in terms of personal -professional preparation, classroom management and average in practice teaching. PTE influences the performance in practice-teaching. As recommendations, pre-service education teachers should attend seminar workshop on language and personality development to be cautious in the medium of communication and on their mannerisms for practice teaching. The department should conduct PTE seminar to make them more prepared for teaching. Future researchers should conduct related study on pre-service- teacher education efficacy.
\end{abstract}

Keywords:

Pre-Service -Teacher Education, Practice -Teaching Performance

Citation:

Paghasian, Margarita C. (2017); Pre-Service- Education and Practice-Teaching Performances among the Fourth Year Bachelor of Elementary Education Students of Mindanao State University- Maigo School of Arts and Trades; Journal of Social Sciences (COES\&RJ-JSS), Vol.6, No.2 Special, pp: 114-125. 


\section{Introduction}

Teaching is a multi-faceted human activity that involves a wide range of planning, strategies, interactions, organizational arrangement and material resources that take place in the teaching-learning process. Teaching requires that its practitioners clearly understand what should be done to bring about the most desirable learning in the learner and be highly proficient in the skills necessary to carry out tasks. It does do not only impart theoretical knowledge but also practical knowledge and skills on pedagogy. Pre-service teacher education (PSTE) program is the first form of professional study that individuals complete to enter the teaching profession. At the end of all the sessions in the classroom, the prospective teachers carry out their theoretical understandings and apprehensions to the field through practice-teaching. Moreover, the practice-teaching program (PTP) is designed to prepare student teachers for the leadership role they are to perform as regular teachers. It enables them to have a genuine task on the nature of teaching experiences. It provides the link between practice-teaching on campus and actual work they will do in the future. Practice-teaching is really intended for student teachers to continue their introduction in the field of teaching with the goal of helping to educate the youth of today. Student teaching leads the future teacher to understand student-teaching experiences as well as teaching itself which involves many challenging tasks, and require hard work. However, such difficult tasks are regarded of having rendered invaluable services in helping young children (Guiab, 2016).

To be ready with this task, teaching practicum involves student teachers, cooperating teachers, university supervisors, administrators, and students. It entails many different considerations, such as lesson plans, observation reports, visits of mentors, and the like. During the teaching practicum, student teachers basically benefit from lesson observation and engage with the cooperating teacher and practicum school, university supervisors' supervision, communication with other school members, and the peer teachers (Gan, 2014). This program typically consists of a blend of theoretical knowledge about teaching and a field-based practice experience. Pre-service-Teacher Education (PSTE) program affects teachers' practice, effectiveness, and career commitment. The quality of teaching and learning taking place in the classroom depends on and reflects the quality of the PSTE.. High-quality of PSTE program can go a long way in the success of the development of the activities that aim to improve the quality of teaching and learning for all children (Roness, 2010). Eventually, it enhances professional growth of the teacher being planned in such a way that it leads to the development of a positive attitude of a prospective teachers towards education and towards improving the performance in terms of better student learning (Rahman et. al. 2011).

As the last field study course, practice teachers should be given all the opportunities to bring out the best in them. This is necessary in order that they could fulfill their goals in the mastery competencies needed as clearly spelled out in the National Competency-Based Standards for Teachers (NCBTS) and CMO 30, s.2004 and its regional adaptation. The internship program is a joint responsibility of Department of Education, teacher- education institutions, both public and private, cooperating school officials, cooperating teachers and college supervisors. They should endeavor to help prospective teachers obtain first-hand experiences in all aspects of teaching. Prospective teachers are challenged in knowing themselves better, in understanding the nature and aspirations of their students, and in acquiring the basic teaching skills in making a critical analysis of the various problems related to teaching. Their practice teaching experiences will help them develop their 
competencies in teaching as well as their social skills. Laruan as cited by Ganal (2016) identified the problems and difficulties student teachers encountered during their offcampus. These are: teachers' personal preparation that includes emotional and social aspect of the student teacher; teachers' professional preparation that includes class participation, school adjustment, problems in workloads and guidance problems; and classroom management that includes instructional and evaluation problems. It is a known fact that student teachers lack the skills and capability to perform with success the role of a teacher. They experience problems and difficulties as regards to instruction, classroom management, evaluating learning outcomes, school, learners, teachers and community adjustment and others. Problems which confront them require urgency and importance to minimize their prevalence to make them develop and sustain self-efficacy thus perform with quality and excellence. Success in student-teaching depends largely on the studentteachers' personal and professional qualities. The success also relies on how well cooperating teachers trained student-teachers how to teach effectively, manage classroom discipline and other related functions. During the student teaching phase, the studentteacher develops either a genuine love for or an aversion for teaching. This explains why cooperating teachers who are assigned to assist the student teacher should possess competencies that are necessary for developing the teaching skills of the studentteachers. This can be traced in the performance of these students in terms of grades.

Walvoord and Anderson as cited by Svinicki, M. D., \& McKeachie, W. J. (2011) espoused that grades in the realm of education are standardized measurements of varying levels of comprehension within a subject area. Grades serve as an evaluation of student work and a means of communicating to students, parents, guardians on how students perform in school. They are potential for further success as a source of motivation to students for continued learning and improvement. Practices related to grading both as an assessment of student performance and as a mechanism through which students receive feedback on their work vary widely across disciplines, course levels, departments, institutions and instructors. However, there are several strategies that most instructors agree contribute to successful grading: creating clear grading criteria, communicating these criteria to students, giving constructive feedback and employing time management strategies when grading large amounts of student work.

As part of the curriculum, the fourth-year BEEd students of MSU-MSAT are required to undergo practice-teaching. In the initial survey being conducted, it revealed that $100 \%$ or thirty students are ready to undergo the practicum. Excited as they were, it was found out that $70 \%$ or twenty one them admitted their feelings of uneasiness. It emerged that participants were worried that they might not meet the expectations of their cooperating teachers and principal, and their goals may not be realized when confronted by mentor apathy and learners' hostility. Considering these, the researcher decided to pursue a study on the readiness of the students to embark on a teaching practicum.

This study focused on pre-service education and practice-teaching performances of the fourth year BEEd students of Mindanao State University-Maigo School of Arts and Trades (MSU-MSAT) during the academic year 2015-2016.

Specifically, this study sought to achieve the following objectives:

1. To identify the pre-service-teacher education in terms of personal preparation, professional preparation and classroom management of the fourth year BEEd students; 
2. To determine the practice-teaching performances in terms of Grade in Practice Teaching (Ed 197);

3. To find out the significant relationship between pre-service education of the students and their practice-teaching performances.

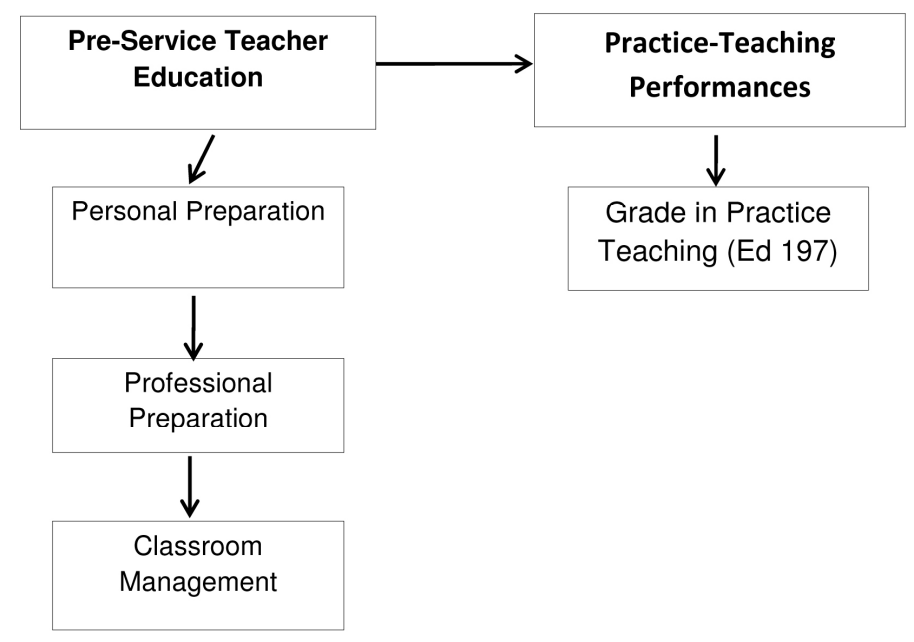

Figure1. Schematic Presentation of the Study

\section{Methods}

This study used the descriptive method which involved the description, recording, analysis, and interpretation of the present nature, composition, or processes of phenomena (Calderon and Gonzales, 2013). The respondents were the 30 fourth year BEEd students of MSU-MSAT in Maigo, Lanao del Norte.

A questionnaire was employed as the main tool in gathering the needed information. It was composed of 30 items adopted from Samson as cited by Ganal (2015). The responses on Pre-service teacher education were analyzed and interpreted using the scale below:

$\begin{array}{llll}\text { Weight } & \text { Scale } & \text { Responses } & \text { Interpretation } \\ 5 & (4.20-5.00) & \text { Always } & \text { Outstanding } \\ 4 & (3.40-4.19) & \text { Often } & \text { Very Satisfactory } \\ 3 & (2.60-3.39) & \text { Sometimes } & \text { Satisfactory } \\ 2 & (1.80-2.59) & \text { Rarely } & \text { Moderately } \\ & & & \text { Satisfactory } \\ 1 & (1.00-1.79) & \text { Never } & \text { Unsatisfactory }\end{array}$


Pre-Service- Education and Practice-Teaching Performances ...

The students' practice-teaching performances were interpreted using the scale below:

$\begin{array}{lll}\text { Weight } & \text { Scale } & \text { Interpretation } \\ 5 & (1.00-1.79) & \text { Excellent } \\ 4 & (1.80-2.59) & \text { Very Good } \\ 3 & (2.60-3.39) & \text { Good } \\ 2 & (3.40-4.19) & \text { Fair } \\ 1 & (4.20-5.00) & \text { Poor }\end{array}$

The questionnaire was referred to the thesis adviser for corrections and suggestions. Being an adopted instrument, it has undergone few modifications and enhancements to suit it with the situation. Fielding of the instrument was done personally to ensure clarity and avoid misinterpretation of the items in the questionnaire. The data gathered were tabulated, analyzed and interpreted using the following statistical instruments:

Frequency and Percentage. These were used to determine the proportion of the respondents' response.

Formula:

$$
\mathrm{P}=\mathrm{F} / \mathrm{n} \times 100 \%
$$

Where:

$$
\begin{aligned}
& \mathrm{P}=\text { Percentage } \\
& \mathrm{F}=\text { Frequency } \\
& \mathrm{n}=\text { Total number of respondents }
\end{aligned}
$$

Average-weighted Mean. This was used to describe the value of responses.

Formula:

$$
\mathrm{X}=
$$

Where:

$\mathrm{X} \quad=$ average-weighted mean

$=$ sum of all the products of and, where is the

frequency of each option

$$
=\text { sum of all subjects }
$$

Chi-square. This was used to determine the significance of the relationship between pre-service-teacher education and practice-teaching performances.

Formula: 


$$
\begin{array}{ll}
\mathrm{X}^{2}=\sum & \\
\text { Where: } & \\
\mathrm{X}^{2} & =\text { Chi-square } \\
\mathrm{O} & =\text { Observed frequency } \\
\mathrm{E} & =\text { Expected frequency }
\end{array}
$$

\section{Results and discussions}

The results and discussions on the findings relative to the study on pre-service teacher education and practice-teaching performances among the fourth year BEEd students of MSU-MSAT are arranged in the following order:

A. Pre-service Teacher Education in terms of Personal Preparation, Professional Preparation and Classroom Management;

B. Practice-Teaching Performances in terms of Grade in Practice Teaching (Ed 197);

C. Significance of the Relationship between the Pre-service Teacher Education of BEEd students and their Practice-Teaching Performances.

\section{Pre-service Teacher Education}

Personal Preparation

Table 1shows the pre-service education of the students in terms of their personal preparation.

Table 1

Pre-Service Teacher Education in terms of Personal Preparation

\begin{tabular}{|l|l|l|l|l|l|l|l|}
\hline Personal Preparation & $\begin{array}{l}\mathrm{A} \\
(5)\end{array}$ & $\begin{array}{l}\mathrm{O} \\
(4)\end{array}$ & $\begin{array}{l}\mathrm{S} \\
(3)\end{array}$ & $\begin{array}{l}\mathrm{R} \\
(2)\end{array}$ & $\begin{array}{l}\mathrm{N} \\
(1)\end{array}$ & AWM & $\mathrm{I}$ \\
\hline 1. I come to class early. & 28 & 2 & & & & 4.93 & $\mathrm{O}$ \\
\hline 2. I come to school ready. & 21 & 9 & & & & 4.70 & $\mathrm{O}$ \\
\hline $\begin{array}{l}\text { I am involved in social activities in } \\
\text { cooperating school. }\end{array}$ & 14 & 10 & 6 & & & 4.27 & $\mathrm{O}$ \\
\hline 4. I move with poise. & 9 & 16 & 5 & & & 4.13 & VS \\
\hline 5. I am properly groomed. & 18 & 12 & & & & 4.60 & O \\
\hline 6. I avoid unnecessary mannerism. & 8 & 11 & 10 & 1 & & 3.87 & VS \\
\hline 7. I am good in diction. & 5 & 21 & 4 & & & 4.03 & VS \\
\hline $\begin{array}{l}\text { I involved myself in social activities in the } \\
\text { cooperating school. }\end{array}$ & 14 & 8 & 8 & & & 4.20 & O \\
\hline 9. I am creative and resourceful & 6 & 14 & 10 & & & 3.87 & VS \\
\hline 10. I avoid favoritism. & 30 & & & & & 5.00 & O \\
\hline General-Weighted Mean & & & & $\mathbf{4 . 3 6}$ & O \\
\hline
\end{tabular}


Table 1 shows that out of 30 respondents, statements "I avoid favoritism" had the highest average weighted value of 5 interpreted as "outstanding", and the statement "I avoid unnecessary mannerisms" had the lowest average-weighted value of 3.73 interpreted as "very satisfactory". The table disclosed a general-weighted mean of 4.26 which was interpreted as "outstanding".

This implies that most of the students are prepared to be fair and impartial and few of them avoid mannerisms.

Table 1-A

Summary Assessment of Pre-Service Teacher Education in Terms of Personal Preparation

\begin{tabular}{|l|l|l|l|}
\hline SCORE & INTERPRETATION & FREQUENCY & PERCENTAGE \\
\hline $4.20-5.0$ & Outstanding & 19 & 63.33 \\
\hline $3.40-4.19$ & Very Satisfactory & 10 & 33.33 \\
\hline $2.60-3.39$ & Satisfactory & 1 & 3.33 \\
\hline $1.80-2.59$ & Moderately Satisfactory & 0 & 0.00 \\
\hline $1.0-1.79$ & Unsatisfactory & 0 & 0.00 \\
\hline Total & 30 & 100.00 \\
\hline
\end{tabular}

The table reveals the summary assessment of the students' pre-service teacher education in terms of personal preparation.

Professional Preparation

Table 2 shows the pre-service teacher education in terms of professional preparation.

Table 2

Pre-Service Teacher Education in Terms of Professional Preparation

\begin{tabular}{|l|l|l|l|l|l|l|l|}
\hline Professional Preparation & $\begin{array}{l}\mathrm{A} \\
(5)\end{array}$ & $\begin{array}{l}\mathrm{O} \\
(4)\end{array}$ & $\begin{array}{l}\mathrm{S} \\
(3)\end{array}$ & $\begin{array}{l}\mathrm{R} \\
(2)\end{array}$ & $\begin{array}{l}\mathrm{N} \\
(1)\end{array}$ & AWM & $\mathrm{I}$ \\
\hline 1. I am prepared. & 20 & 10 & & & & 4.67 & $\mathrm{O}$ \\
\hline $\begin{array}{l}\text { I can write lesson plan based on the } \\
\text { teacher's guide. }\end{array}$ & 12 & 9 & 9 & & & 4.10 & $\mathrm{VS}$ \\
\hline $\begin{array}{l}\text { have sufficient lesson activities so pupils } \\
\text { are not doing anything. }\end{array}$ & 6 & 21 & 3 & & & 4.10 & $\mathrm{VS}$ \\
\hline 4. I provide variety of activities. & 7 & 16 & 7 & & & 4.00 & $\mathrm{VS}$ \\
\hline 5. My strategies are well-planned. & 14 & 11 & 5 & & & 4.30 & $\mathrm{O}$ \\
\hline $\begin{array}{l}\text { I come to school with well-prepared } \\
\text { instructional materials }\end{array}$ & 30 & 0 & & & & 5.00 & $\mathrm{O}$ \\
\hline $\begin{array}{l}\text { I have good command of English and } \\
\text { Filipino languages. }\end{array}$ & 1 & 25 & 4 & & & 3.90 & $\mathrm{VS}$ \\
\hline $\begin{array}{l}\text { I avoid making mistakes in front of the } \\
\text { class. }\end{array}$ & 15 & 4 & 10 & 1 & & 4.10 & VS \\
\hline $\begin{array}{l}\text { I have sufficient understanding of the } \\
\text { subject matter. }\end{array}$ & 17 & 11 & 2 & & & 4.50 & $\mathrm{O}$ \\
\hline
\end{tabular}




\begin{tabular}{|l|l|l|l|l|l|l|l|}
\hline 10. I am interested in teaching. & 30 & & & & & 5.00 & $\mathrm{O}$ \\
\hline General- Weighted Mean & & $\mathbf{4 . 3 7}$ & $\mathrm{O}$ \\
\hline
\end{tabular}

Table 2 shows that out of 30 respondents, the statement "I am interested in teaching "had the highest average-weighted mean of 5 interpreted as "outstanding" and the statement " I have good command of English and Filipino languages" had the lowest average-weighted mean of 3.90 interpreted as "very satisfactory". The data disclosed a general-weighted mean of 4.37 which was interpreted as "outstanding".

This implies that most of the pre-service teachers are interested in teaching but they have average command in English and Filipino languages.

Table 2-A

Summary Assessment of Pre-Service Teacher Education in Terms of Professional Preparation

\begin{tabular}{|l|l|l|l|}
\hline SCORE & INTERPRETATION & FREQUENCY & PERCENTAGE \\
\hline $4.20-5.0$ & Outstanding & 16 & 53.33 \\
\hline $3.40-4.19$ & Very Satisfactory & 13 & 43.33 \\
\hline $2.60-3.39$ & Satisfactory & 1 & 3.33 \\
\hline $1.80-2.59$ & Moderately Satisfactory & 0 & 0.00 \\
\hline $1.0-1.79$ & Unsatisfactory & 0 & 0.00 \\
\hline Total & 30 & 100.00 \\
\hline
\end{tabular}

The table reveals the summary on pre-service education in terms of personal preparation.

Classroom Management

Table 3 shows the pre-service teacher education in terms of classroom management. Table 3

Pre-Service Teacher Education in terms of Classroom Management

\begin{tabular}{|l|l|l|l|l|l|l|l|}
\hline Classroom Management & $\begin{array}{l}\mathrm{A} \\
(5)\end{array}$ & $\begin{array}{l}\mathrm{O} \\
(4)\end{array}$ & $\begin{array}{l}\mathrm{S} \\
(3)\end{array}$ & $\begin{array}{l}\mathrm{R} \\
(2)\end{array}$ & $\begin{array}{l}\text { N } \\
(1)\end{array}$ & AWM & I \\
\hline manage my classroom independently. & 7 & 13 & 9 & 1 & & 3.87 & $\mathrm{VS}$ \\
\hline can perform effectively routine activities. & 27 & 2 & 1 & & & 4.87 & $\mathrm{O}$ \\
\hline $\begin{array}{l}\text { I can enhance learning activities by } \\
\text { structuring my classroom. }\end{array}$ & 7 & 15 & 8 & & & 3.97 & $\mathrm{VS}$ \\
\hline $\begin{array}{l}\text { prepare visual aids and other instructional } \\
\text { materials. }\end{array}$ & 28 & 2 & & & & 4.93 & $\mathrm{O}$ \\
\hline $\begin{array}{l}\text { I select activities to carry out the different } \\
\text { parts of the lesson. }\end{array}$ & 14 & 13 & 3 & & & 4.37 & $\mathrm{O}$ \\
\hline 6. I can maintain interest of my pupils & 5 & 13 & 12 & & & 3.77 & $\mathrm{VS}$ \\
\hline am effective in introduction and motivation. & 13 & 15 & 2 & & & 4.37 & $\mathrm{VS}$ \\
\hline
\end{tabular}


Pre-Service- Education and Practice-Teaching Performances ...

\begin{tabular}{|l|l|l|l|l|l|l|l|}
\hline 8. I can handle different subject matters. & 28 & 1 & 1 & & & 4.90 & O \\
\hline $\begin{array}{l}\text { I can formulate behavioral objectives in the } \\
\text { cognitive, affective and psychomotor } \\
\text { domains of learning. }\end{array}$ & 5 & 16 & 5 & 4 & & 3.73 & VS \\
\hline $\begin{array}{l}\text { I have the ability to develop the lesson in } \\
\text { relation to the objectives. }\end{array}$ & 4 & 14 & 5 & 7 & & 3.50 & VS \\
\hline General-weighted Mean & $\mathbf{4 . 2 3}$ & $\mathrm{O}$ \\
\hline
\end{tabular}

Table 3 shows that out of 30 respondents, the statement "I prepare visual aids and other instructional materials" got the highest average-weighted mean of 4.93 interpreted as "outstanding" and the statement "I have the ability to develop the lesson in relation to the objectives" had the lowest average-weighted mean of 3.50 interpreted as "very satisfactory". The table disclosed a general-weighted mean of 4.23 which was interpreted as "outstanding".

This implies that most of the pre-service teachers are ready to make visual aids and other instructional materials and have the ability to develop the lesson in relation to the objectives.

Table 3-A

Summary Assessment of the Pre-Service Teacher Education in terms of Classroom Management

\begin{tabular}{|l|l|l|l|}
\hline Score & INTERPRETATION & FREQUENCY & PERCENTAGE \\
\hline $4.20-5.0$ & Outstanding & 16 & 53.33 \\
\hline $3.40-4.19$ & Very Satisfactory & 12 & 40.00 \\
\hline $2.60-3.39$ & Satisfactory & 2 & 6.67 \\
\hline $1.80-2.59$ & Moderately Satisfactory & 0 & 0.00 \\
\hline $1.0-1.79$ & Unsatisfactory & 0 & 0.00 \\
\hline Total & 30 & 100.00 \\
\hline
\end{tabular}

The table reveals the summary on pre-service education in terms of classroom management.

Practice-Teaching Performances

Table 4 shows the students' practice-teaching performances.

Table 4

Students' Practice-Teaching Performances in terms of Grade in Practice Teaching

(Ed 197)

\begin{tabular}{|l|l|l|l|}
\hline $\begin{array}{l}\text { Grade in Practice } \\
\text { Teaching (Ed 197) }\end{array}$ & Interpretation & Frequency & Percentage \\
\hline $1.00-1.25$ & Excellent & 0 & 0.00 \\
\hline $1.50-1.75$ & Very Good & 11 & 36.67 \\
\hline $2.00-2.25$ & Good & 19 & 63.33 \\
\hline $2.50-2.75$ & Satisfactory & 0 & 0.00 \\
\hline 3 & Passing & 0 & 0.00 \\
\hline
\end{tabular}




\begin{tabular}{|l|l|l|l|}
\hline 5 & Failed & 0 & 0.00 \\
\hline Total & 30 & $100 \%$ \\
\hline
\end{tabular}

Table 4 shows that out of 30 respondents, 36.67 percent or 11 students had grade of "1.50-1.75" interpreted as "very good", and 63.33 percent or 19 students had grade of "2.00-2.25". This implies that most of the students have good practice-teaching performances.

\section{Significance of the Relationship between the Pre-service Teacher Education of the Students and their Practice-Teaching Performances Table 5}

Summary Table on the Significance of the Relationship between the Pre-service Education of the Students and their Practice-Teaching Performances

\begin{tabular}{|l|l|l|l|l|l|l|}
\hline $\begin{array}{l}\text { Pre-service } \\
\text { Teacher Education }\end{array}$ & $\mathrm{x}^{2}$ & $\mathrm{df}$ & $\mathrm{p}$ & $\mathrm{cv}$ & Decision & Interpretation \\
\hline $\begin{array}{l}\text { Personal } \\
\text { Preparation }\end{array}$ & 5.45 & 1 & 0.05 & 3.84 & Rejected & Significant \\
\hline $\begin{array}{l}\text { Professional } \\
\text { Preparations }\end{array}$ & 4.75 & 1 & 0.05 & 3.84 & Rejected & Significant \\
\hline $\begin{array}{l}\text { Classroom } \\
\text { management }\end{array}$ & 8.64 & 1 & 0.05 & 3.84 & Rejected & Significant \\
\hline
\end{tabular}

$\mathrm{H}_{\mathrm{o}}$ : There is no significant relationship between the pre-service teacher education of the students and their practice-teaching performances.

The table above presents the summary data about the significance of the relationship between the pre-service teacher education in terms of personal preparation, professional preparation and classroom management of the students and their practice-teaching performances.

Personal Preparation

The computed chi-square value of 5.45 was more than the critical values of 3.84 with 1 degree of freedom at 0.05 level of probability. The analysis reveals that there was a significant relationship between the pre-service teacher education and the respondents' grade in practice teaching ( $\mathrm{Ed} 197)$ in terms of personal preparations. The null hypothesis was rejected suggesting that the respondents' pre-service-teacher education in personal preparation is a factor that affects the students' practice-teaching performances.

\section{Professional Preparation}

The computed chi-square value of 4.75 was more than the critical value of 3.84 with 1 degree of freedom at 0.05 level of probability. The analysis revealed that there was significant relationship between the pre-service teacher education and the respondents' grade in practice teaching (Ed 197) in terms of professional preparation. Hence, the null hypothesis was rejected suggesting that the respondents' the pre-service teacher education 
in professional preparation is a factor that affects the students' practice-teaching performances.

Classroom Management

The computed chi-square value of 8.64 was more than the critical value of 3.84 with 1 degree of freedom at 0.05 level of probability. The analysis revealed that there was significant relationship between the pre-service teacher education in terms of classroom management of the students and their practice-teaching performances. Hence, the null hypothesis was rejected implying that the pre-service teacher education in classroom management of the students is a factor that affects their practice-teaching performances.

\section{Findings, conslusions and recommendations}

\section{Findings}

The study revealed the following as its findings:

1. The pre-service education teachers had an outstanding performance in pre-service teacher education in personal preparation, professional preparation and classroom management.

2. Majority of them have good performance in practice teaching.

3. There was a significant relationship between pre-service teacher education in terms of personal preparation, professional preparation and classroom management and their practice-teaching performances.

\section{Conclusions}

On the basis of the findings of the study, the following conclusions are drawn:

1. The pre-service education teachers have an appreciable performance in terms of personal preparation, professional preparation and classroom management.

2. Majority of the pre-service education teachers have average performances in their practice-teaching.

3. Their pre-service teacher education influences the performance in practice-teaching.

\section{Recommendations}

Based on the conclusions of the study, the recommendations below are offered:

1.Pre-service education teachers should attend seminar workshop on language or speech development.

2.The Department should conduct an orientation or final briefing for pre-service teacher education before their graduation.

3.Pre-service education teachers should be cautious in terms of personal preparation specifically on their mannerisms during practice-teaching.

4.Future researchers should conduct a related study on pre-service teacher education efficacy.

\section{References}

Barton, G. M., Hartwig, K. A., \& Cain, M. (2015). International students' experience of practicum in teacher education: An exploration through internationalization and professional socialization .Education, 40(8), 149-163. Retrieved on May 22, 2016 from https://goo.gl/RcHctE

Calderon, J. \& Gonzales, E. 2013.Methods of research and Thesis writing. Manila: National Book Store 
Cibulka, J., \& Daniel, L. G. (2010, October). An overview of the report of the Blue Ribbon Panel on Clinical Preparation and Partnerships for Improved Student Learning.Presented at the annual fall meeting of the Teacher Education Council of State Colleges and Universities, Indianapolis, IN.

Darling-Hammond, L. (2010).Teacher education and the American future. Journal of Teacher Education, 61(1-2), 35-47. Retrieved on May 26,2016 from https://goo.gl/DkOqJm

DeLuca, 2012.Selecting Inclusive Teacher Candidates: Validity and Reliability Issues in Admission Policy and Practice. Retrieved on May 23,2016 from https://goo.gl/s7iOKv

Futernick, K. (2010). Incompetent Teachers or Dysfunctional Systems? Phi Delta Kappan, 9, 2, 59-64.Retrieved on May 20, 2016 from https://goo.gl/9ZwJ1j

Ganal, N. (2015). Problems of Prospective Teachers of Philippine Normal University, North Luzon Campus During Practice Teaching, Isabela Campus, Alicia, Isabela.Retrieved on May 26,2016 from https://goo.gl/AAW8Pg

$\mathrm{Gu}(2010)$, The New Lives of Teachers. Retrieved on May 22, 2016 https://goo.gl/9FVoLF Hamaidi, PhD (2014). Student-Teachers' Perspectives of Practicum Practices and Challenges, edition vol.10, No.13 ISSN: 1857 - 7881 (Print) e - ISSN 1857- 7431. Retrieved on May 24, 2016 from https://goo.gl/D6KVxQ

Hermosisima, V. (2013). Educational Policy Research and Development Center Philippine Normal University. Retrieved on May 21, 2016 from https://goo.gl/MhIQ8s

Hudson, P. (2012). How Can Schools Support Beginning Teachers? A Call for Timely Induction and Mentoring for Effective Teaching. Retrieved on May 24, 2016 from https://goo.gl/na1osQ

Lesha, J. (2014). Action Research in Education, University of Shkodra" Luigj Gurakuqi", Faculty of Educational Sciences, Shkoder, Alban. Retrieved on May 23, 2016 from https://goo.gl/VFqDPh 